\title{
Neurotransmitter Modulation of Calcium Current in Rat Spinal Cord Neurons
}

\author{
Dinah W. Y. Sah \\ Department of Neurobiology, Harvard Medical School, Boston, Massachusetts 02115
}

\begin{abstract}
The modulation of $\mathrm{Ca}^{2+}$ currents by neurotransmitters was studied in freshly dissociated rat spinal cord neurons, using the whole-cell patch-ciamp technique. GABA, baclofen, adenosine, ATP, serotonin, norepinephrine, somatostatin, and dynorphin $\mathrm{A}$ inhibited the current through $\mathrm{Ca}^{2+}$ channels in a substantial fraction of cells, while substance $P$, vasoactive intestinal polypeptide, [D-ala $\left.{ }^{2}, \mathrm{~d}-l e \mathrm{u}^{5}\right]-$ enkephalin, cholecystokinin-8 (sulfated), calcitonin gene-related peptide, angiotensin II, neurotensin, vasopressin, and thyrotropin-releasing hormone had no effect. In the case of baclofen, the inhibition is mediated, at least in part, by a GTP-binding protein. Suppression of $\mathrm{Ca}^{2+}$ current by neurotransmitters may represent a mechanism of presynaptic inhibition in the spinal cord.
\end{abstract}

Calcium has a primary role in many cellular functions, including exocytosis and excitability. One of the main routes of $\mathrm{Ca}^{2+}$ entry into a cell is via voltage-dependent $\mathrm{Ca}^{2+}$ channels. In peripheral neurons, current through $\mathrm{Ca}^{2+}$ channels can be modulated by a number of neurotransmitters, including adenosine, GABA, norepinephrine, dynorphin $A$, and neuropeptide $Y$ (for reviews, see Dunlap et al., 1987; Miller, 1987; Tsien et al., 1988; Bean, 1989a). However, much less is known about modulation of $\mathrm{Ca}^{2+}$ channels in central neurons, despite suggestions that presynaptic inhibition in the CNS involves depression of $\mathrm{Ca}^{2+}$ currents (Pierau and Zimmermann, 1973; Phillis et al., 1979; Murase et al., 1982). Recently, adenosine (Madison et al., 1987) and muscarine (Gahwiler and Brown, 1987) have been reported to inhibit $\mathrm{Ca}^{2+}$ currents in hippocampal pyramidal neurons, while norepinephrine has been reported to enhance $\mathrm{Ca}^{2+}$ currents in hippocampal granular neurons (Gray and Johnston, 1987). It is clearly of interest to determine whether neurotransmitter modulation of $\mathrm{Ca}^{2+}$ channels is a widespread phenomenon in the CNS and to identify the range of transmitters capable of such modulation.

I have recorded $\mathrm{Ba}^{2+}$ currents through $\mathrm{Ca}^{2+}$ channels from freshly dissociated rat spinal cord neurons, using the whole-cell patch-clamp technique, and examined the effects of a range of neurotransmitters, including GABA, baclofen, adenosine (ado), ATP, 5-HT, norepinephrine (NE), substance P (SP), somatostat-

Received Apr. 13, 1989; revised July 10, 1989; accepted July 13, 1989.

I thank Dr. B. P. Bean, Dr. J. Huettner, and L. Regan for helpful suggestions, and for reading the manuscript. I am grateful to $P$. Ceelen for providing most of the neurons used in these experiments. This work was supported by grants to $B$. P. Bean from the NIH (HL35034) and the Rita Allen Foundation; D.W.Y.S. was supported by NIH training grant NS07112.

Correspondence should be addressed to Dinah W. Y. Sah, Department of Neurobiology, Harvard Medical School, 220 Longwood Avenue, Boston, MA 02115. Copyright (c) 1990 Society for Neuroscience $0270-6474 / 90 / 010136-06 \$ 02.00 / 0$ in (SOM), dynorphin A (dyn A), [D-ala ${ }^{2}$, d-leu $\left.{ }^{5}\right]$-enkephalin (DADLE), vasoactive intestinal polypeptide (VIP), chloecystokinin-8, sulfated $\left(\mathrm{CCK}-8_{\mathrm{s}}\right)$, calcitonin gene-related peptide (CGRP), neurotensin (NT), angiotensin II $\left(\mathrm{AT}_{\mathrm{II}}\right.$ ), thyrotropinreleasing hormone (TRH), and vasopressin (ADH). Here, I report that GABA, baclofen, adenosine, ATP, 5-HT, NE, SOM, and dyn $\mathrm{A}$ inhibit the current through $\mathrm{Ca}^{2+}$ channels in a substantial proportion of cells, while the remaining transmitters have no significant effect. These observations support the idea that suppression of $\mathrm{Ca}^{2+}$ current might represent a mechanism of presynaptic inhibition in central neurons. In peripheral neurons, transmitter inhibition of $\mathrm{Ca}^{2+}$ currents is mediated by GTP-binding proteins (Holz et al., 1986; Dolphin and Scott, 1987; Ewald et al., 1988). Similarly, inhibition of $\mathrm{Ba}^{2+}$ current by baclofen in spinal cord neurons involves G-proteins. When intracellular GTP is replaced by the hydrolysis-resistant analog, GTP- $\gamma-\mathrm{S}$, inhibition by baclofen no longer reverses readily in most cells. Furthermore, after neurons are incubated with perlussis toxin, their $\mathrm{Ba}^{2}$ currents are no longer responsive to baclofen. Thus, currents through $\mathrm{Ca}^{2+}$ channels in spinal cord neurons, like those in peripheral neurons, are modulated in an inhibitory manner by a number of neurotransmitters. In the case of baclofen, the inhibition probably involves G-proteins.

\section{Materials and Methods}

Experiments were performed on neurons freshly dissociated from the spinal cord of neonatal rats (P2-P11). Neurons were dispersed as previously described by Huettner and Baughman (1986), except that some cells were treated with trypsin Type XI (Sigma, $0.7 \mathrm{mg} / \mathrm{ml}$ ). Two populations of cells were readily distinguishable by appearance: a predominant population with round or oval somata of relatively small diameter $(10-20 \mu \mathrm{m})$ and a scarce population with irregular somata of relatively large diameter $(>30 \mu \mathrm{m})$. Only cells from the former population were selected for study; these probably represent interneurons, while the others probably consist of motoneurons (Brown, 1981).

The whole-cell recording mode was used, and currents were filtered at 1 kIIz. Patch pipettes had impedances of 5-15 M $\Omega$ and contained the following (in $\mathrm{mm}$ ): $120 \mathrm{Cs}$-methanesulfonate, $5 \mathrm{Mg}(\mathrm{OH})_{2}, 5 \mathrm{CsCl}$, 10 EGTA, 10 HEPES, and an ATP-regenerating solution (Forscher and Oxford, 1985), pH 7.40. The ATP-regeneration solution consisted of $14 \mathrm{~mm}$ creatine phosphate, $4 \mathrm{~mm} \mathrm{MgATP}, 0.3 \mathrm{~mm}$ GTP, and 50 units/ ml creatine phosphokinase (Type I, from rabbit muscle). Although series resistance compensation was not used, voltage errors were small; the product of peak current and series resistance (estimated from the time constant of the capacity transient divided by cell capacitance) was 4.2 $\pm 0.8 \mathrm{mV}$ (SEM, $n=10$ ). The cells were allowed to adhere to a glass coverslip and perfused slowly at room temperature with Tyrode's solution ( $\mathrm{pH} 7.40$ ) containing (in mM): $150 \mathrm{NaCl}, 4 \mathrm{KCl}, 2 \mathrm{CaCl}_{2}, 2 \mathrm{MgCl}_{2}$, 10 glucose, $10 \mathrm{HEPES}$, and, in most experiments, $4 \mathrm{BaCl}_{2}$. After the whole-cell recording mode was attained, control solution ( $160 \mathrm{~mm}$ TEA$\mathrm{Cl}, 5 \mathrm{mM} \mathrm{BaCl}, 10 \mathrm{mM}$ HEPES, and 1-3 $\mu \mathrm{M}$ tetrodotoxin) was applied to the cells, in order to isolate $\mathrm{Ba}^{2+}$ currents through $\mathrm{Ca}^{2+}$ channels. For application of agonists, a series of 6-8 microcapillary tubes $(1 \mu \mathrm{l}$ Drummond "Microcaps") was glued together, side-by-side. Solutions 


$\begin{array}{lll}\begin{array}{l}\text { Table 1. Neurotransmitter modulation of } \mathrm{Ba}^{2+} \text { current in spinal cord } \\ \text { neurons }\end{array} & \begin{array}{l}\text { Proportion of cells } \\ \text { with }>10 \% \text { decrease }\end{array} & \begin{array}{l}\text { Mean decrease } \\ \text { in } I_{\mathrm{Ba}} \text { (range) }\end{array} \\ \text { in } I_{\mathrm{Ba}} & 51(15-75) \\ \text { Agonist } & 30 / 30 & 41(13-63) \\ \text { GABA } & 30 / 30 & 32(16-50) \\ \text { Baclofen } & 15 / 16 & 26(15-40) \\ \text { Adenosine } & 4 / 11 & 36(18-60) \\ \text { ATP } & 9 / 14 & 28(20-40) \\ \text { 5-HT } & 7 / 10 & \\ \text { NE } & 0 / 10 & \\ \text { Angiotensin II } & 0 / 8 & 45 \\ \text { CCK-8 } & 0 / 10 & 22(15-35) \\ \text { CGRP } & 1 / 5 & 17 \\ \text { DADLE } & 5 / 7 & 39(26-50) \\ \text { Dynorphin A } & 1 / 8 & 15 \\ \text { Neurotensin } & 7 / 14 & \\ \text { Somatostatin } & 0 / 12 & \\ \text { Substance P } & 1 / 13 & \\ \text { TRH } & 0 / 4 & \\ \text { Vasopressin } & 0 / 7 & \\ \text { VIP } & & \end{array}$

$\overline{\text { Neurotransmitter modulation of } \mathrm{Ba}^{2+} \text { current in spinal cord neurons. Conventional }}$ transmitters: $10 \mu \mathrm{M}$; peptides: $1 \mu \mathrm{M}$. Holding potentials: -100 to $-70 \mathrm{mV}$; test potentials: -20 to $0 \mathrm{mV}$. Currents were measured $5-10 \mathrm{msec}$ after stepping to the test potential. The mean decrease in current is the average inhibition in cells that responded ( $>10 \%$ decline).

were fed from separate reservoirs by gravity and, in some experiments, by additional pressure. The microcapillary tubes were mounted on a micromanipulator, which was used for moving the tubes relative to the cell in order to change solutions. All experiments were done at $20-25^{\circ} \mathrm{C}$.

The following agonists were obtained from Sigma: GABA, adenosine, ATP, 5-HT-creatinine sulfate, NE-bitartrate, substance $P$, somatostatin, DADLE, CGRP, neurotensin, angiotensin II, and vasopressin. Dynorphin A, porcine VIP, CCK-8 (sulfated), and TRH were obtained from Peninsula, while $( \pm$ ) baclofen and muscimol were obtained from Research Biochemicals Inc. Frozen stocks of agonists were thawed and diluted on the day of the experiment into a solution ( $\mathrm{pH} 7.40$ ) containing $160 \mathrm{~mm}$ TEA-Cl, $5 \mathrm{~mm} \mathrm{BaCl}_{2}, 10 \mathrm{~mm}$ HEPES, and $1-3 \mu \mathrm{M}$ tetrodotoxin. Pertussis toxin was obtained from Sigma, while GTP- $\gamma-S$ was obtained from Sigma or Boehringer-Mannheim.

\section{Results}

More than $90 \%$ of the cells obtained by the dissociation procedure were of small diameter $(10-20 \mu \mathrm{m})$ and had round or oval somata, with no processes or very short processes $(<40$ $\mu \mathrm{m}$ in length); these probably represent interneurons, based on their size and predominance, and were selected for recording. $\mathrm{Ba}^{2+}$ currents through $\mathrm{Ca}^{2+}$ channels were evoked by stepping from holding potentials of -100 to $-70 \mathrm{mV}$ to test potentials of -20 to $0 \mathrm{mV}$. GABA ( $10 \mu \mathrm{M}$; Fig. $1 A$, Table 1$)$ inhibited the inward voltage-dependent current by approximately half, on average, with more than $10 \%$ inhibition in every cell tested. However, effects of GABA on $\mathrm{Ba}^{2+}$ current were difficult to analyze in detail since $\mathrm{GABA}$ also activates a $\mathrm{Cl}^{-}$conductance in these cells, via the $\mathrm{GABA}_{\mathrm{A}}$ receptor. The effects of GABA on $\mathrm{Ba}^{2+}$ current were mimicked by the selective $\mathrm{GABA}_{\mathrm{B}}$ agonist, baclofen ( $10 \mu \mathrm{M}$; Fig. $1 B$, Table 1$)$, which inhibited $\mathrm{Ba}^{2+}$ currents by nearly half, on average, with more than $10 \%$ inhibition in every cell tested. Baclofen reduced $\mathrm{Ba}^{2+}$ currents without a shift in reversal potential, consistent with a selective effect on $\mathrm{Ba}^{2+}$ current. Furthermore, the inward current in the presence of
A

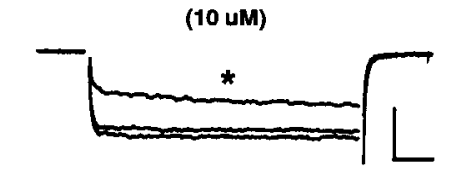

E $\quad$ 5-HT

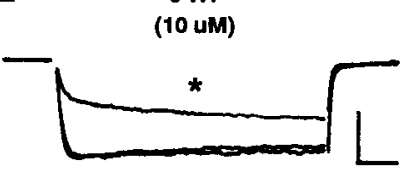

B

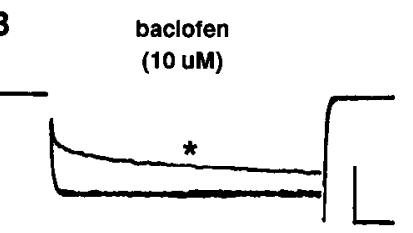

$\mathbf{F}$

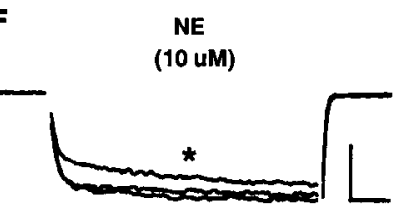

C
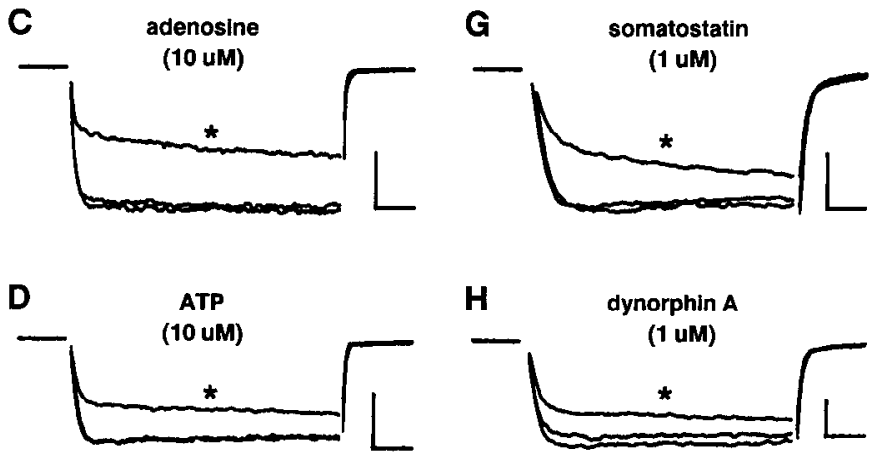

Figure 1. Effects of GABA $(A)$, baclofen $(B)$, adenosine $(C)$, ATP $(D)$, 5-HT $(E)$, NE $(F)$, somatostatin $(G)$, and dynorphin A $(H)$ on leaksubtracted $\mathrm{Ba}^{2+}$ currents in freshly dissociated spinal cord neurons. The agonists were applied in $160 \mathrm{~mm}$ TEA-Cl, $5 \mathrm{~mm} \mathrm{BaCl}_{2}, 10 \mathrm{~mm}$ HEPES, and $1-3 \mu \mathrm{M}$ TTX, $\mathrm{pH}$ 7.40. Holding potential: $-70 \mathrm{mV}(A-F)$ and -80 $\mathrm{mV}(G-H)$; test potential: $-10 \mathrm{mV}$. Horizontal calibration bars: 10 msec; vertical calibration bars: $100 \mathrm{pA}(A, F-H)$, and $200 \mathrm{pA}(B-E)$. An asterisk indicates the current recorded in the presence of agonist; the other traces represent currents recorded in control solution, before and after application of agonist.

baclofen was completely blocked by $1-3 \mathrm{mM} \mathrm{Cd}^{2+}(n=3)$. The effect of baclofen on $\mathrm{Cd}^{2+}$-sensitive current is shown in Figure 2 . Thus, baclofen selectively inhibits the voltage-dependent current through $\mathrm{Ca}^{2+}$ channels, while GABA probably inhibits inward current by 2 mechanisms-decreasing current through $\mathrm{Ca}^{2+}$ channels and increasing $\mathrm{Cl}^{-}$current.

Adenosine $(10 \mu \mathrm{M})$ inhibited the voltage-dependent current through $\mathrm{Ca}^{2+}$ channels in every cell tested, except one, with an average decrease of approximately one-third (Fig. 1C, Table 1). In contrast, ATP $(10 \mu \mathrm{M})$ inhibited the current in fewer cells, with a somewhat smaller effect than adenosine (Fig. $1 D$, Table 1). The amines, 5-HT (10 $\mu \mathrm{M}$; Fig. $1 E)$ and NE (10 $\mu \mathrm{M}$; Fig. $1 F)$, each reduced the current in most cells, with an average inhibition of approximately one-third (Table 1). Of 11 neuropeptides tested (all at $1 \mu \mathrm{M}$ ), only 2, SOM and dyn A, affected the current through $\mathrm{Ca}^{2+}$ channels in a substantial proportion of cells (Table 1). SOM (Fig. 1G, Table 1) inhibited the current in half of the cells tested, by an avcragc of $39 \%$, whilc dyn A (Fig. $1 H$, Table 1) inhibitcd the current to a smaller extent. DADLE and NT were found to inhibit the current in only one case each, while SP, VIP, CCK$8_{\mathrm{s}}, \mathrm{CGRP}, \mathrm{AT}_{\mathrm{II}}, \mathrm{ADH}$, and TRH had no significant effect in any of the cells tested. There was no correlation between sensitivity to NE and sensitivity to SOM, 5-HT, or dyn A, nor was there a correlation between sensitivity to $5-\mathrm{HT}$ and sensitivity to SOM. 


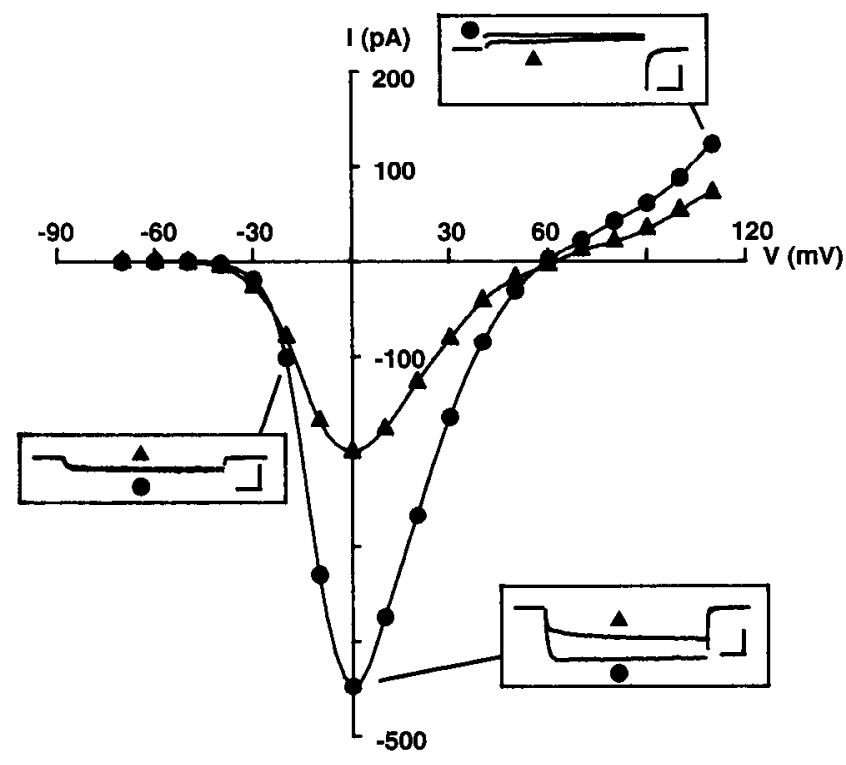

Figure 2. Effect of baclofen $(10 \mu \mathrm{M})$ on current-voltage relation: control; $\Delta$, baclofen. Holding potential: $-70 \mathrm{mV}$. The average current was measured between 4.9 and $6.6 \mathrm{msec}$ after depolarization to the test potential. Current-voltage relations were measured in $160 \mathrm{~mm}$ TEA$\mathrm{Cl}, 5 \mathrm{mM} \mathrm{BaCl}, 10 \mathrm{~mm}$ HEPES, and $1 \mu \mathrm{M}$ TTX with and without 3 $\mathrm{mM} \mathrm{Cd}^{\prime+}$ and with and without baclofen; the $\mathrm{Cd}^{2+}$-sensitive component is plotted here. Insets, Currents are shown for test potentials of -20 , 0 , and $+110 \mathrm{mV}$. Calibration bars: $10 \mathrm{msec}$ and $200 \mathrm{pA}$.

In peripheral neurons, several different neurotransmitters inhibit $\mathrm{Ca}^{2+}$ current via G-proteins (Holz et al., 1986; Dolphin and Scott, 1987; Lipscombe and Tsien, 1987; Wanke et al., 1987; Ewald et al., 1988). To see if the inhibitory effect of baclofen in spinal cord neurons also involves G-proteins, modulation of $\mathrm{Ba}^{2+}$ currents was examined after treatment with PTx or after replacement of intracellular GTP with GTP- $\gamma$-S (Table 2). Overnight treatment with PTx $(100-200 \mathrm{ng} / \mathrm{ml})$ at $35^{\circ} \mathrm{C}$ blocked the effects of baclofen in 10/12 cells (Fig. $3 B$, Table 2). Furthermore, the 2 responsive cells exhibited only small reductions in $\mathrm{Ba}^{2+}$ current (13 and 17\%). Cells incubated in parallel with vehicle had normal responses to baclofen, with an inhibition of $\mathrm{Ba}^{2+}$ current in every cell tested ( $38 \%$ on average).

Table 2. Effect of pertussis toxin and intracellular GTP- $\gamma-S$ on inhibition of $\mathrm{Ba}^{2+}$ current by baclofen

\begin{tabular}{llll} 
& $\begin{array}{l}\text { Proportion } \\
\text { of cclls } \\
\text { with } \\
>10 \% \\
\text { decrease } \\
\text { in } I_{\mathrm{Ba}}\end{array}$ & $\begin{array}{l}\text { Mcan } \\
\text { de- } \\
\text { crease } \\
\text { in } I_{\mathrm{Ba}} \\
(\%)\end{array}$ & $\begin{array}{l}\text { Proportion } \\
\text { of cells } \\
\text { with } \\
>50 \%\end{array}$ \\
$\begin{array}{llll}\text { recovery } \\
\text { from } \\
\text { inhibition }\end{array}$ \\
Addition & & & \\
\hline $\mathrm{GTP}, 0.3 \mathrm{mM}$ & $30 / 30$ & 41 & $30 / 30$ \\
GTP- $\gamma-\mathrm{S}, 100 \mu \mathrm{M}$ & $15 / 15$ & 40 & $5 / 15$ \\
$\begin{array}{l}\text { Vehicle } \\
\text { Pertussis toxin, }\end{array}$ & $6 / 6$ & 38 & - \\
$100-200 \mathrm{ng} / \mathrm{ml}^{a}$ & $2 / 12$ & 15 & -
\end{tabular}

Effect of pertussis toxin and intracellular GTP- $\gamma-\mathrm{S}$ on inhibition of $\mathrm{Ba}^{2+}$ current by baclofen, $10 \mu \mathrm{M}$. Holding potentials: -100 to $-70 \mathrm{mV}$; test potentials: -20 to $0 \mathrm{mV}$. Currents were measured $5-14 \mathrm{msec}$ after stepping to the test potential The mean decrease in current is the average inhibition in cells that responded $(>10 \%$ decline).

"Ovemight at $35^{\circ} \mathrm{C}$

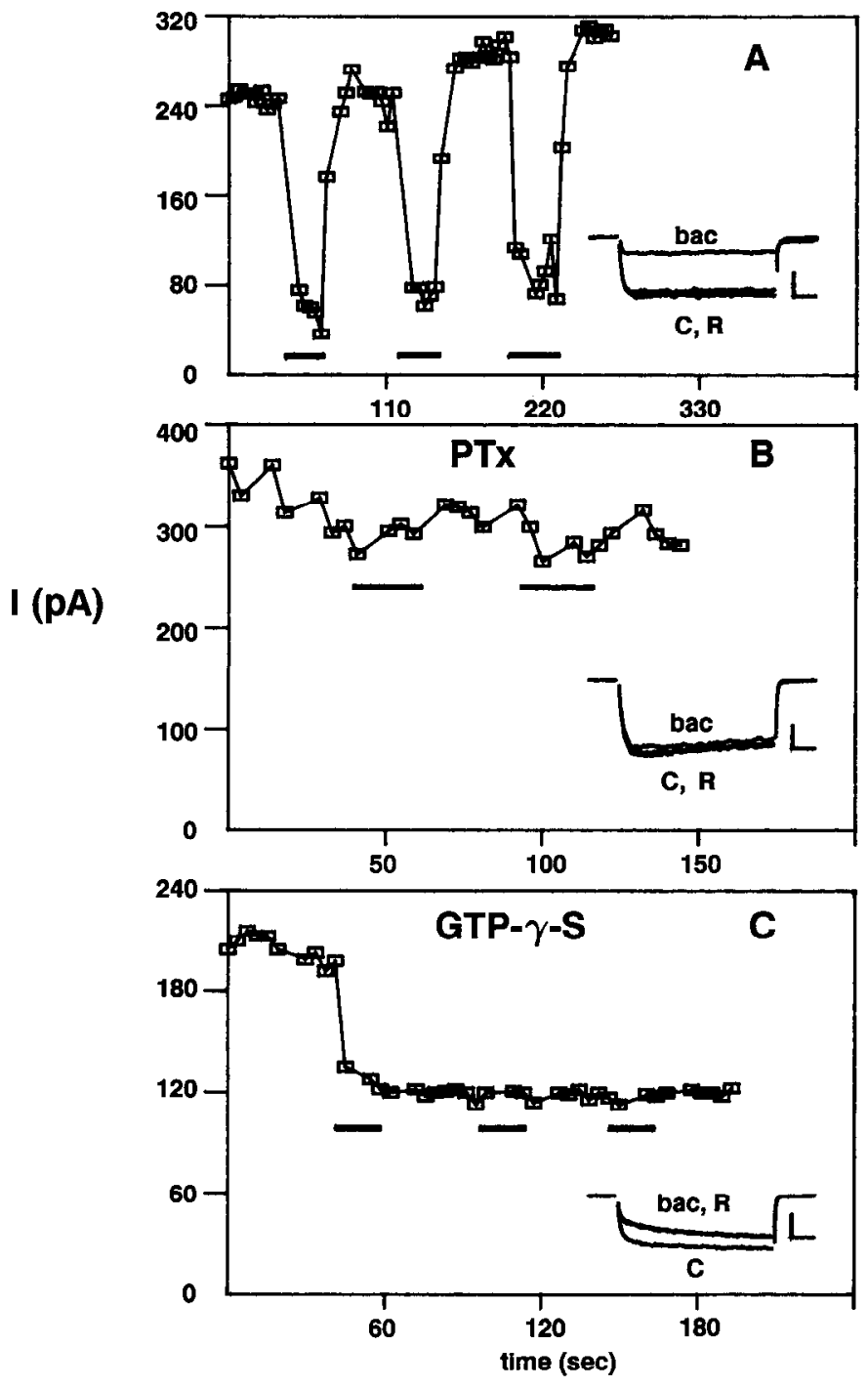

Figure 3. Effect of pertussis toxin and GTP- $\gamma-\mathrm{S}$ on baclofen $(10 \mu \mathrm{M})$ inhibition of $\mathrm{Ba}^{2+}$ currents. $A$, control, with intracellular GTP $(0.3 \mathrm{~mm})$. Baclofen was applied 3 times; the inhibition reversed rapidly and completely each time. Holding potential: $-90 \mathrm{mV}$; test potential: $-10 \mathrm{mV}$. $B$, Pertussis toxin treatment $\left(200 \mathrm{ng} / \mathrm{ml}, 23 \mathrm{hr}\right.$ at $\left.35^{\circ} \mathrm{C}\right)$. Baclofen was applied twice; there was no significant change in $\mathrm{Ba}^{2+}$ current either time. $C$, Intracellular GTP- $\gamma-\mathrm{S}(100 \mu \mathrm{M})$. The first application of baclofen produced a $35 \%$ inhibition of the $\mathrm{Ba}^{2+}$ current. However, the effect was irreversible, and there was no effect of 2 subsequent applications. Currents were measured between 6.4 and $14 \mathrm{msec}$. The solid bars represent the periods of baclofen application. Insets: bac, baclofen; $c$, control; $r$, recovery; calibration bars: $10 \mathrm{msec}$ and $100 \mathrm{pA}$.

Normally, the inhibition of $\mathrm{Ba}^{2+}$ current by baclofen reverses completely and rapidly (within $8 \mathrm{sec}$, Fig. $3 A$ ). When intracellular GTP was replaced with GTP- $\gamma$-S $(100 \mu \mathrm{M})$, the frequency and magnitude of the baclofen effect was the same as that with intracellular GTP. However, in most cells, more than half of the inhibition was irreversible (Fig. $3 C$, Table 2), suggesting that at least that part of the baclofen effect is mediated by a G-protein.

\section{Discussion}

Previous studies of $\mathrm{Ca}^{2+}$ current modulation in central neurons demonstrated inhibitory effects of adenosine (Madison et al., 1987) and muscarine (Gahwiler and Brown, 1987) in rat hippocampal pyramidal neurons, and stimulatory effects of NE via 
$\beta$-receptors in rat hippocampal granular neurons (Gray and Johnston, 1987). Here, it has been shown that $\mathrm{Ca}^{2+}$ channels in spinal cord neurons are modulated in an inhibitory manner by the conventional neurotransmitters, GABA (via B-receptors), adenosine, ATP, 5-HT, and NE. Although a number of peptidergic transmitters are present in the spinal cord (Hökfelt et al., 1976, 1977; Khachaturian et al., 1982), only SOM and dyn A altered $\mathrm{Ba}^{2+}$ currents through $\mathrm{Ca}^{2+}$ channels in a subpopulation of cells; $\mathrm{AT}_{11}$, SP, DADLE, VIP, CCK-8 , CGRP, NT, ADH, and TRH had little effect. None of the transmitters tested increased $\mathrm{Ba}^{2+}$ currents; this parallels the predominance of inhibition in peripheral neurons (Tsien et al., 1988; Bean, 1989a).

GABA is a major inhibitory transmitter in the CNS. In the spinal cord, GABA is present in interneurons (Hunt et al., 1981). GABA was originally described to activate a $\mathrm{Cl}^{-}$conductance, via $\mathrm{GABA}_{\mathrm{A}}$ receptors. More recently, an additional effect was ascribed to GABA in the peripheral nervous system, a decrease in $\mathrm{Ca}^{2+}$ conductance (Dunlap and Fischbach, 1981) via $\mathrm{GABA}_{\mathrm{B}}$ receptors. The specific $\mathrm{GABA}_{\mathrm{B}}$ receptor agonist, baclofen, has inhibitory actions on central neurons which have been attributed to 2 mechanisms: an increase in potassium conductance (Newberry and Nicoll, 1984) and presynaptic inhibition, resulting in suppression of postsynaptic potentials (Pierau and Zimmermann, 1973). The mechanism of presynaptic inhibition was postulated to be a reduction in $\mathrm{Ca}^{2+}$ current; however, baclofen had no detectable effect on $\mathrm{Ca}^{2+}$ action potentials in slices from adult rat cortex (Howe et al., 1987) or on $\mathrm{Ca}^{2+}$ currents in hippocampal neurons cultured from neonatal rats (Gahwiler and Brown, 1985). In contrast, in spinal cord neurons freshly dissociated from neonatal rats, baclofen substantially decreases currents through $\mathrm{Ca}^{2+}$ channels. The discrepancy between the results reported here and those in cortical slices may be explained by regional tissue differences (spinal cord versus cortex and hippocampus), animal age (neonatal versus adult), culture age (freshly dissociated versus 3-5 weeks in vitro), or sensitivity of method (direct measurement of current through $\mathrm{Ca}^{2+}$ channels with voltage-clamp versus length of $\mathrm{Ca}^{2+}$ action potential). There is actually no discrepancy between the observations described here and the experiments with cultured hippocampal neurons (Gahwiler and Brown, 1985), since in the latter study, the effect of baclofen was only examined on currents elicited with $20 \mathrm{mV}$ depolarizing steps. For small depolarizations, there is similarly no effect of baclofen on $\mathrm{Ba}^{2+}$ currents in spinal cord neurons (see Fig. 2). (The reason for the lack of effect with small depolarizations remains to be determined; it could arise from differential effects on different types of $\mathrm{Ca}^{2+}$ channels-see Lipscombe and Tsien, 1987). The inhibitory effects of baclofen on current through $\mathrm{Ca}^{2+}$ channels in spinal cord neurons are qualitatively similar to those reported in sensory neurons (Dunlap and Fischbach, 1981; Dolphin and Scott, 1987) and may play a role in presynaptic inhibition of transmission in central neurons.

$\mathrm{G}$-proteins have been shown to mediate inhibition of $\mathrm{Ca}^{2+}$ current by NE and baclofen in chick DRG neurons (Holz et al., 1986); adenosine and baclofen (Dolphin and Scott, 1987), and NPY (Ewald et al., 1988) in rat DRG neurons; enkephalin in neuroblastoma-glioma cells (Hescheler et al., 1987); and SOM in a pituitary cell line (Lewis et al., 1986). Similarly, baclofen modulation of currents through $\mathrm{Ca}^{2+}$ channels in spinal cord neurons appears to be mediated, at least in part, by G-proteins, since the inhibition was blocked by preincubation with pertussis toxin, and the recovery from inhibition (in most cells) hampered with intracellular GTP- $\gamma-S$. However, in 5 of 15 cells perfused internally with GTP- $\gamma-\mathrm{S}$, more than $50 \%$ of the baclofen effect reversed readily (within $30 \mathrm{sec}$ ). This may have been due to the presence of residual intracellular GTP. Unlike rat DRG neurons (Dolphin and Scott, 1987), the magnitude of the inhibitory effects of baclofen in spinal cord neurons is not altered with GTP$\gamma-\mathrm{S}$. Nevertheless, the action of baclofen on currents through $\mathrm{Ca}^{2+}$ channels in spinal cord neurons is consistent with the current model of G-protein signal transduction (Dunlap et al., 1987; Neer and Clapham, 1988).

Adenosine is a potent inhibitor of firing rate in central neurons, while ATP has strong excitatory effects (Phillis et al., 1979). A number of experiments on transmitter release (Fredholm and Hedqvist, 1980; Dolphin and Archer, 1983) and synaptic transmission (Phillis et al., 1979; Dunwiddie and Hoffer, 1980) indicate that the inhibitory effects of adcnosine arc probably due to inhibition of transmitter release from presynaptic terminals (Stone, 1981). Since adenosine-receptor agonists inhibit $\mathrm{Ca}^{2+}$ influx into synaptosomes (Wu et al., 1982), presynaptic inhibition may result from a decrease in presynaptic $\mathrm{Ca}^{2+}$ current. The results reported here, as well as those reported for sensory neurons (Dolphin et al., 1986; Macdonald et al., 1986) and hippocampal pyramidal neurons (Madison et al., 1987), support such a mechanism.

ATP excites a population of neurons from the dorsal horn of the spinal cord (Fyffe and Perl, 1984) by increasing a TTXinsensitive sodium conductance (Jahr and Jessell, 1983). The inhibitory effects on current through $\mathrm{Ca}^{2+}$ channels seen here may be due to an additional effect of ATP or to adenosine after enzymatic degradation of ATP (Stone, 1981).

The spinal cord receives descending serotonergic and adrenergic inputs from the raphé nucleus (Fuxe, 1965; Hökfelt et al., 1978; Steinbusch et al., 1978) and locus coeruleus (Carlsson et al., 1964), respectively; these projections arborize in the dorsal and ventral horns. Electrophysiological studies suggest that 5-HT and NE may contribute to analgesia by inhibiting spinal transmission of nociceptive impulses (Akil and Mayer, 1972; Basbaum et al., 1976; Headley et al., 1978; Reddy and Yaksh, 1980). The inhibitory effects of 5-HT and NE on current through $\mathrm{Ca}^{2+}$ channels reported here are qualitatively similar to their effects in sensory neurons (Forscher and Oxford, 1985; Holz et al., 1986; Deisz and Lux, 1988) and may mediate suppression of synaptic transmission.

In the rat spinal cord, immunocytochemical studies have provided evidence for the presence of neuropeptides. Johansson et al. (1984) have demonstrated that there are numerous SOMpositive cells in lamina II, with a high density of immunoreactive fibers in the dorsal horn, particularly in lamina II; some of these fibers represent terminals of a population of sensory neurons that contain SOM (Hökfelt et al., 1976). Similarly, dynorphin is localized within fibers and a few cells of the marginal zone of the dorsal horn (Khachaturian et al., 1982), while enkephalin is localized within interneurons and descending terminals (Hökfelt et al., 1977). The physiological effects of these peptides in the spinal cord are generally inhibitory (Basbaum et al., 1976; Kelly, 1982). In the cat, SOM depresses the firing rate of nociceptive dorsal horn neurons (Randic and Miletic, 1978). Intracellular recordings from rat dorsal horn neurons in the slice preparation (Murase et al., 1982) showed that SOM and enkephalin hyperpolarized most cells, with a decrease in membrane resistance and firing rate; Murase et al. suggest that at least part of this effect may be presynaptic since it was reduced 
by a low $\mathrm{Ca}^{2+} /$ high $\mathrm{Mg}^{2+}$ solution. The results reported here are consistent with presynaptic inhibitory effects of SOM and dyn A via reductions in $\mathrm{Ca}^{2+}$ current. The effect of SOM in the spinal cord is qualitatively similar to those reported in rat sympathetic neurons (Ikeda et al., 1987) and pituitary (Lewis et al., 1986) and neuroblastoma-glioma (Tsunoo et al., 1986) cell lines, while that of dyn $A$ resembles its action on mouse sensory neurons (Gross and Macdonald, 1987).

In the present study, there was no detectable effect of SP on currents through $\mathrm{Ca}^{2+}$ channels in spinal cord neurons. In contrast, Murase et al. (1986) report that SP's excitatory effects in the spinal cord slice preparation are mediated by an augmentation of $\mathrm{Ca}^{2+}$ current, in addition to suppression of $\mathrm{K}^{+}$current (Nowak and Macdonald, 1982). A possible explanation for the discrepancy is enzymatic degradation of the SP receptor during the dissociation procedure used for the experiments described here. However, voltage-clamp data in slice preparations may be difficult to interpret due to poor voltage control and contaminating $\mathrm{K}^{+}$currents. Furthermore, the effect of SP in the slice preparation may be at least partially transsynaptic, consistent with its mimicry by agents that enhance $\mathrm{Ca}^{2+}$ current and blockade by agents that suppress $\mathrm{Ca}^{2+}$ current (Murase et al., 1986).

Whole-cell and single-channel recordings in peripheral neurons have recently demonstrated the existence of 3 channel types-L, N, and T (Nowycky et al., 1985); multiple types of $\mathrm{Ca}^{2+}$ current have been described in central neurons as well (see Tsien et al., 1988; Bean, 1989a). Selective modulation of N-current has been reported for ACh (Wanke et al., 1987), adenosine (Madison et al., 1987), and dyn A (Gross and Macdonald, 1987). In the present study, suppression of current through $\mathrm{Ca}^{2+}$ channels was generally greater at the beginning of the voltage step than at the end (sec Fig. 1), with no consistent differences among the effective transmitters (excluding GABA). The implications of this slowing in kinetics, with respect to channel type (Tsien et al., 1988; Bean, 1989a) and mechanism (Bean, $1989 \mathrm{~b})$ remain to be determined.

The great majority of neurons in the spinal cord are interneurons, outnumbering motoneurons 30:1 (Henneman, 1980). They serve as points of convergence; most primary sensory fibers and descending fibers terminate on interneurons, and most of the synaptic boutons on motoneurons represent terminations from interneurons. Thus, interneurons play a dominant role in information processing within the spinal cord. The neurons studied in the experiments described here are likely to be interneurons, based on their predominance and size. Inhibition of their $\mathrm{Ca}^{2+}$ currents by GABA (via B-receptors), adenosine, ATP, 5-HT, NE, SOM, and dyn A may represent a mechanism of modulating their output in vivo.

\section{References}

Akil, H., and D. J. Mayer (1972) Antagonism of stimulation-produced analgesia by p-CPA, a serotonin synthesis inhibitor. Brain Res. 44: 692-697.

Basbaum, A. I., C. H. Clanton, and H. L. Fields (1976) Opiate and stimulus-produced analgesia: Functional anatomy of a medullospinal pathway. Proc. Natl. Acad. Sci. USA 73: 4685-4688.

Bean, B. P. (1989a) Classes of calcium channels in vertebrate cells. Annu. Rev. Physiol. 51: 367-384.

Bean, B. P. (1989b) Neurotransmitter inhibition of neuronal calcium currents by changes in channel voltage-dependence. Nature 340: $153-$ 156.

Brown, A. G. (1981) Organization in the Spinal Cord, Springer-Verlag, New York
Carlsson, A., A. Dahlstrom, K. Fuxe, and N.-A. Hillarp (1964) Cellular localization of monoamines in the spinal cord. Acta Physiol. Scand. 60: 112-119.

Deisz, R. A., and H. D. Lux (1988) $\gamma$-aminobutyric acid-induced depression of calcium currents of chick sensory neurons. Neurosci. Lett. 56: 205-210.

Dolphin, A. C., and E. R. Archer (1983) An adenosine agonist inhibits and a cyclic AMP analogue enhances the release of glutamate but not GABA from slices of rat dentate gyrus. Neurosci. Lett. 43: 49-54.

Dolphin, A. C., and R. H. Scott (1987) Calcium channel currents and their inhibition by $(-)$-baclofen in rat sensory ncuroncs: Modulation by guanine nucleotides. J. Physiol. (Lond.) 386: 1-17.

Dolphin, A. C., S. R. Forda, and R. H. Scott (1986) Calcium-dependent currents in cultured rat dorsal root ganglion neurones are inhibited by an adenosine analogue. J. Physiol. (Lond.) 373: 47-61.

Dunlap, K., and G. D. Fischbach (1981) Neurotransmitters decrease the calcium conductance activated by depolarization of embryonic chick sensory neurones. J. Physiol. (Lond.) 317: 519-535.

Dunlap, K., G. G. Holz, and S. G. Rane (1987) G proteins as regulators of ion channel function. Trends Neurosci. 10: 241-244.

Dunwiddie, T. V., and B. J. Hoffer (1980) Adenine nucleotides and synaptic transmission in the in vitro rat hippocampus. Br. J. Pharmacol. 69: 59-68.

Ewald, D. A., P. D. Sternweis, and R. J. Miller (1988) Guanine nucleotide-binding protcin $G_{0}$-induced coupling of ncuropeptide $Y$ receptors to $\mathrm{Ca}^{2+}$ channels in sensory neurons. Proc. Natl. Acad. Sci. USA 85 : 3633-3637.

Forscher, P., and G. S. Oxford (1985) Modulation of calcium channels by norepinephrine in internally dialyzed avian sensory neurons. $\mathbf{J}$. Gen. Physiol. 85: 743-763.

Fredholm, B. B., and P. Hedqvist (1980) Modulation of neurotransmission by purine nucleotides and nucleotides. Biochem. Pharmacol 29: 1635-1643.

Fuxe, K. (1965) Evidence for the existence of monoamine neurons in the central nervous system - IV. Distribution of monoamine nerve terminals in the central nervous system. Acta Physiol. Scand. (Suppl.) 247: $36-85$.

Fyffe, R. E. W., and E. R. Perl (1984) Is ATP a central synaptic mediator for certain primary afferent fibers from mammalian skin? Proc. Natl. Acad. Sci. USA 81: 6890-6893.

Gahwiler, B. H., and D. A. Brown (1985) GABA $_{B}$-receptor-activated $\mathrm{K}^{+}$current in voltage-clamped CA3 pyramidal cells in hippocampal cultures. Proc. Natl. Acad. Sci. USA 82: 1558-1562.

Gahwiler, B. H., and D. A. Brown (1987) Muscarine affects calciumcurrents in rat hippocampal pyramidal cells in vitro. Neurosci. Lett. 76: 301-306.

Gray, R., and D. Johnston (1987) Noradrenaline and $\beta$-adrenoceptor agonists increase activity of voltage-dependent calcium channels in hippocampal neurons. Nature 327: 620-622.

Gross, R. A., and R. L. Macdonald (1987) Dynorphin A selectively reduces a large transient (N-type) calcium current of mouse dorsal root ganglion neurons in cell culture. Proc. Natl. Acad. Sci. USA 84. 5469-5473.

Headley, P. M., A. W. Duggan, and B. T. Griersmith (1978) Selective reduction by noradrenaline and 5-hydroxytryptamine of nociceptive responses of cat dorsal horn neurones. Brain Res. 145: 185-189.

Henneman, E. (1980) Organization of the spinal cord and its reflexes. In Medical Physiology, Vol. 1, V. B. Mountcastle, ed., pp. 762-786, C. V. Mosby, St. Louis.

Hescheler, J., W. Rosenthal, W. Trautwein, and G. Shultz (1987) The GTP-binding protein, $\mathrm{G}_{a}$, regulates neuronal calcium channels. Nature 325: 445-447.

Hökfelt, T., R. Elde, O. Johansson, R. Luft, G. Nilsson, and A. Arimura (1976) Immunohistochemical evidence for separate populations of somatostatin-containing and substance $\mathrm{P}$-containing primary afferent neurons in the rat. Neuroscience $1: 131-136$.

Hökfclt, T., R. Eldc, O. Johansson, L. Tcrenius, and L. Stein (1977) The distribution of enkephalin-immunoreactive cell bodies in the rat central nervous system. Neurosci. Lett. 5: 25-31.

Hökfelt, T., A. Ljungdahl, H. Steinbusch, A. Verhofstad, G. Nilsson, E. Brodin, B. Pernow, and M. Goldstein (1978) Immunohistochemical evidence of substance P-like immunoreactivity in some 5-hydroxytryptamine-containing neurons in the rat central nervous system. Neuroscience 3: 517-538.

Holz, G. G., S. G. Rane, and K. Dunlap (1986) GTP-binding proteins 
mediate transmitter inhibition of voltage-dependent calcium channels. Nature 319: 670-672.

Howe, J. R., B. Sutor, and W. Zeiglgansberger (1987) Baclofen reduces postsynaptic potentials of rat cortical neurones by an action other than its hyperpolarizing action. J. Physiol. (Lond.) 384: 539-569.

Huettner, J. E., and R. W. Baughman (1986) Primary culture of identified neurons from the visual cortex of postnatal rats. J. Neurosci. 6: 3044-3060.

Hunt, S. P., J. S. Kelly, P. C. Emson, J. R. Kimmel, R. J. Miller, and J.-Y. Wu (1981) An immunohistochemical study of neuronal populations containing neuropeptides or $\gamma$-aminobutyrate within the superficial layers of the rat dorsal horn. Neuroscience 6: 1883-1898.

Ikeda, S. R., G. G. Schofield, and F. F. Weight (1987) Somatostatin blocks a calcium current in acutely isolated adult rat superior cervical ganglion neurons. Neurosci. Lett. 81: 123-128.

Jahr, C. E., and T. M. Jessell (1983) ATP excites a subpopulation of rat dorsal horn neurones. Nature 304: 730-733.

Johansson, O., T. Hökfelt, and R. P. Elde (1984) Immunohistochemical distribution of somatostatin-like immunoreactivity in the central nervous system of the adult rat. Neuroscience 13: 265-339.

Kelly, J. S. (1982) Electrophysiology of peptides in the central nervous system. Br. Med. Bull. 38: 283-290.

Khachaturian, H., S. J. Watson, M. E. Lewis, D. Coy, A. Goldstein, and $H$. Akil (1982) Dynorphin immunocytochemistry in the rat central nervous system. Peptides 3: 941-954.

Lewis, D. L., F. F. Weight, and A. Luini (1986) A guanine nucleotidebinding protein mediates the inhibition of voltage-dependent calcium current by somatostatin in a pituitary cell line. Proc. Natl. Acad. Sci. USA 83: 9035-9039.

Lipscombe, D., and R. W. Tsien (1987) Noradrenaline inhibits N-type Ca channels in frog sympathetic neurones. J. Physiol. (Lond.) 377: 97P.

Macdonald, R. L., J. H. Skerritt, and M. A. Wertz (1986) Adenosine agonists reduce voltage-dependent calcium conductance of mouse sensory neurones in cell culture. J. Physiol. (Lond.) 370: 75-90.

Madison, D. V., A. P. Fox, and R. W. Tsien (1987) Adenosine reduces an inactivating component of calcium current in hippocampal CA3 neurons. Biophys. J. 51: 30a.

Miller, R. J. (1987) Calcium channels in neurones. In Structure and Physiology of the Slow Inward Calcium Channel, Vol. 1, D. J. Triggle and J. C. Venter, eds., pp. 161-246, Liss, New York.

Murase, K., V. Nedeljkov, and M. Randic (1982) The actions of neuropeptides on dorsal horn neurons in the rat spinal cord slice preparation: An intracellular study. Brain Res. 234: 170-176.

Murase, K., P. D. Ryu, and M. Randic (1986) Substance P augments a persistent slow inward calcium-sensitive current in voltage-clamped spinal dorsal horn neurons of the rat. Brain Res. 365: 369-376.

Neer, E. J., and D. E. Clapham (1988) Roles of G protein subunits in transmembrane signalling. Nature 333: 129-134.

Newherry, N. R., and R. A. Nicoll (1984) Direct hyperpolarizing action of baclofen on hippocampal pyramidal cells. Nature 308:450452.

Nowak, L. M., and R. L. Macdonald (1982) Substance P: Ionic basis for depolarizing responses of mouse spinal cord neurons in cell culture. J. Neurosci. 2: 1119-1128.

Nowycky, M. C., A. P. Fox, and R. W. Tsien (1985) Three types of neuronal calcium channel with different calcium agonist sensitivity. Nature 316: 440-443.

Phillis, J. W., J. P. Edstrom, G. K. Kostopoulos, and J. R. Kirkpatrick (1979) Effects of adenosine and adenine nucleotides on synaptic transmission in the cerebral cortex. Can. J. Physiol. Pharmacol. 57: $1289-1312$

Pierau, F. K., and P. Zimmermann (1973) Action of a GABA-derivative on postsynaptic potentials and membrane properties of cats' spinal motoneurones. Brain Res. 54: 376-380.

Randic, M., and V. Miletic (1978) Depressant actions of methionineenkephalin and somatostatin in cat dorsal horn neurones activated by noxious stimuli, Brain Res. 152: 196-202.

Reddy, S. V. R., and T. L. Yaksh (1980) Spinal noradrenergic terminal system mediates antinociception. Brain Res. 189: 391-401.

Steinbusch, H. W. M., A. J. Verhofstad, and H. W. J. Joosten (1978) Localization of serotonin in the central nervous system by immunohistochemistry: Description of a specific and sensitive technique and some applications. Neuroscience 3: 811-819.

Stone, T. W. (1981) Physiological roles of adenosine and adenosine 5 -triphosphate in the nervous system. Neuroscience 6: 523-555.

Tsien, R. W., D. Lipscombe, D. V. Madison, K. R. Bley, and A. P. Fox (1988) Multiple types of neuronal calcium channels and their selective modulation. Trends Neurosci. $11: 431-438$.

Tsunoo, A., M. Yoshi, and T. Narahashi (1986) Block of calcium channels by enkephalin and somatostatin in neuroblastoma-glioma hybrid NG108-15 cells. Proc. Natl. Acad. Sci. USA 83: 9832-9836.

Wanke, E., A. Ferroni, A. Malgaroli, A. Ambrosini, T. Pozzan, and J. Meldolesi (1987) Activation of a muscarinic receptor selectively inhibits a rapidly inactivated $\mathrm{Ca}^{2+}$ current in rat sympathetic neurons. Proc. Natl. Acad. Sci. USA 84: 4313-4317.

Wu, P. H., J. W. Phillis, and D. L. Thierry (1982) Adenosine receptor agonists inhibit $\mathrm{K}^{+}$-evoked $\mathrm{Ca}^{2+}$ uptake by rat brain cortical synaptosomes. J. Neurochem. 39: 700-708. 